\title{
TREE COVER DIAGNOSIS OF SÃO PAULO CITY
}

Rafaela Novaes de Abreu ${ }^{1}$, Bruna Lara de Arantes ${ }^{1}$, Gustavo Torquatro Oliva ${ }^{1}$, Jefferson Lordello Polizel $^{1}$; Demóstenes Ferreira da Silva Filho ${ }^{1}$

${ }^{1}$ Escola Superior de Agricultura "Luiz de Queiroz" - Universidade de São Paulo, Piracicaba, SP, Brasil. E-mail: rafabreu@usp.br, blarantes@usp.br, gustavo.oliva@usp.br, jlpolize@usp.br, dfilho@usp.br

\section{ABSTRACT}

Cities land use and landscape management are a big challenge for public sectors managers, who should search for low costs, efficient tools and scientific evidences that can improve these actions. This study aimed at comparing supervised classification of aerial images from 2002 and 2009, through MultiSpec W32, of tree cover diagnosis of São Paulo city. Land use indices and occupation were determined in selected sub regions of micro watersheds. It was possible to observe the metropolis growth dynamics and the urban forest adaptive changes. It was concluded that, in most regions, the exposed soil of 2002 was replaced by constructions in 2009, increasing the number of shadows on the region. The micro watershed with more trees, in both years, was the one of the Belini stream.

Keywords: GIS, MultiSpec, urban forest management, urban trees

\section{DIAGNÓSTICO DA COBERTURA ARBÓREA DA CIDADE DE SÃo PAULO}

\section{RESUMO}

Foi realizado um diagnóstico da cobertura arbórea da cidade de São Paulo, através de classificação supervisionada das imagens aéreas de 2002 e 2009 pelo MultiSpec W32, com fins comparativos. As sub-regiões escolhidas foram microbacias hidrográficas, nas quais foram determinados índices de uso e ocupação do solo, que permitem acompanhar a dinâmica do crescimento da Metrópole Paulistana e como a floresta urbana tem se adaptado a essas mudanças. Na maioria das regiões observouse que o solo exposto de 2002 foi ocupado por construções em 2009, aumentando o número de sombreamento na região. A microbacia mais arborizada em ambos os anos foi a do Córrego Belini.

Palavras-chave: SIG, MultiSpec, manejo da floresta urbana, arborização urbana 


\section{INTRODUCTION}

The increase in space consumption and the disordered growth of cities contribute to the green areas reduction and the degradation of life quality (LOMBARDO, 1990).

Urban forest is an important agent in the climate improvement because it increases humidity and reduces the temperature, avoiding heat islands and reducing pollution as it intercepts the particulate material and the stomata absorb the air pollutants, in addition to the aesthetics function (BONAMETTI, 2003).

Remote sensing and geoprocessing techniques are important to obtain information regarding the urban forest visualization and quantification, being an economical and efficient method that allows a general view of the studied regions (XIAO et al., 1999). In addition, it is possible to get information on the urban forest, such as free space and leaf area indices, used to model the benefits generated by it (NOWAK et al., 1996).

São Paulo city total area is $1,523 \mathrm{~km}^{2}$, from which $760 \mathrm{~km}^{2}$ correspond to green areas. However, this area is not divided into areas of gardens, tree plantations, parks, squares and conservation areas, but rather as total plant area (MOREIRA et al., 2007).

In this study, the city of São Paulo was divided according to the watersheds present in each region, which objective was to quantify and compare the urban forest in the years of 2002 and 2009.

\section{MATERIALS AND METHODS}

São Paulo is the biggest city in Brazil, with a population of 11.253 .503 people. It is located in $23^{\circ} 32^{\prime} 0^{\prime \prime} \mathrm{S}$ and $46^{\circ} 37^{\prime} 0^{\prime \prime} \mathrm{W}$, with an extension of 1,521 $\mathrm{km}^{2}$ and average altitude of 860 meters (IBGE, 2013; CEPAGRI, 2013). The city has dry winter and hot summer, a Cwa climate type according to the Köppen-Geiger classification (KOTTEK et al., 2006).

It was studied the regions covered by the following watersheds: Aclimação; Anhangabaú; Belini; Branca; Cassandoca; Corujas; Curtume; Luz; Fortunato Ferraz; Glicério; Iguatemi; Morenguinho; Parque da Móoca; Sapateiro; Saracura; Tiburrinho; Uberaba; Verde I; Verde II; Dreno do Brooklin; Pacaembú; Traição; and Vinte e Três de Maio.

In order to carry out the study, images from Ikonos satellite of the year 2002 and images from Quickbird satellite of the year 2009 were used, both in the geotiff format, with squares of $5 \mathrm{~km} \times 5 \mathrm{~km}$ and four bands: NIR (near infrared, that highlights the vegetation); Green; Blue and Red. 
Following Silva Filho (2006) methodology, the satellite images were classified through the MultiSpec 3.2 free software. In the classification, five Training samples and five Test samples were prepared, totaling ten samples for each class. The watersheds regions image elements were classified according to the following classes: background; tree cover; lawn; exposed land; asphalt; shade; river/lake; pool; light roof; dark roof; gray roof; and ceramic roof.

Also, in the MultiSpec 3.2 software, the image classification statistical analysis was performed using the Kappa index, which indicates when some class presents pixels misclassified. This index ranges from 0.01 to 0.99 , and the closer to 1.0 the more accurate the analysis.

It was accepted only thematic maps resulting in Kappa values equal or above $81 \%$, which accuracy is considered almost perfect from Landis \& Koch (1977) evaluation.

In order to analyze the accuracy of the supervised classification the Kappa index is widely used, since it includes all the elements of the error matrix (CONGALTON, 2001). The formula for obtaining the index was described in Landis \& Koch (1997).

To evaluate the classification accuracy, omission and commission errors were analyzed, which equations were demonstrated in Ferreira et al. (2007). It was analyzed the result obtained from the subtraction between the omission and commission errors of the $100 \%$ that were tabulated.

And finally, to investigate whether major changes happened in urban space from 2002 (Ikonos satellite image) to 2009 (Quickbird satellite image), the percentages of thematic classes and scatter plots in Excel software were compared to analyze possible correlations between the years, through determination coefficient $\left(\mathrm{R}^{2}\right)$, that demonstrates how much of the total variation is common to the set of analyzed elements (CONTI, 2009). It varies from 0 to 1 , the closer to 1 the greater the correlation between the variables (BAESSO \& SOUZA, 2010).

\section{RESULTS AND DISCUSSION}

Omission and commission errors analysis are detailed in Table 1. The results indicate that occur a minimum percentage of error, which validates tree cover and lawn classification.

The classes classification results under discussion are presented in Table 2. 
Table 1. Omission and Commission percentage of tree cover and lawn supervised classification from Ikonos and Quickbird satellite images (São Paulo, SP, 2013).

\begin{tabular}{|c|c|c|c|c|c|c|c|c|}
\hline \multirow{4}{*}{ Watersheds } & \multicolumn{8}{|c|}{ Classes } \\
\hline & \multicolumn{4}{|c|}{ Tree cover (\%) } & \multicolumn{4}{|c|}{ Lawn (\%) } \\
\hline & \multirow{2}{*}{\multicolumn{2}{|c|}{$\begin{array}{c}\text { IKONOS } \\
(\mathbf{2 0 0 2 )} \\
\text { Omission / } \\
\text { Commission } \\
\end{array}$}} & \multirow{2}{*}{\multicolumn{2}{|c|}{$\begin{array}{c}\begin{array}{c}\text { QUICKBIRD } \\
(2009)\end{array} \\
\text { Omission / } \\
\text { Commission }\end{array}$}} & \multirow{2}{*}{\multicolumn{2}{|c|}{$\begin{array}{c}\text { IKONOS } \\
(2002) \\
\text { Omission / } \\
\text { Commission } \\
\end{array}$}} & \multirow{2}{*}{\multicolumn{2}{|c|}{$\begin{array}{c}\begin{array}{c}\text { QUICKBIRD } \\
(2009)\end{array} \\
\text { Omission / } \\
\text { Commission } \\
\end{array}$}} \\
\hline & & & & & & & & \\
\hline Aclimação & 99.3 & 99.8 & 98.3 & 98.5 & 100 & 92.3 & 99.1 & 97.6 \\
\hline Anhangabaú & 97.1 & 74.5 & 100 & 99.5 & 63.3 & 92.6 & 97.6 & 100 \\
\hline Belini & 98.4 & 99.0 & 97.6 & 99.4 & 97.9 & 96.7 & 98.4 & 93.8 \\
\hline Branca & 93.2 & 78.5 & 94.0 & 99.5 & 85.4 & 95.4 & 99.4 & 91.0 \\
\hline Cassandoca & 98.1 & 97.6 & 98.1 & 96.8 & 93.4 & 90.9 & 91.6 & 95.2 \\
\hline Corujas & 99.0 & 98.5 & 97.6 & 97.7 & 99.1 & 95.1 & 98.2 & 97.3 \\
\hline Curtume & 85.5 & 97.4 & 100 & 100 & 98.2 & 89.6 & 100 & 100 \\
\hline Luz & 98.1 & 99.2 & 98.9 & 100 & 97.7 & 93.9 & 99.7 & 85.9 \\
\hline $\begin{array}{l}\text { Fortunato } \\
\text { Ferraz }\end{array}$ & 98.8 & 99.7 & 97.1 & 99.7 & 99.3 & 97.6 & 99.4 & 92.5 \\
\hline Glicério & 98.9 & 95.9 & 80.7 & 99.7 & 98.9 & 98.6 & 99.6 & 48.8 \\
\hline Iguatemi & 96.8 & 99.7 & 100 & 100 & 100 & 87.0 & 100 & 100 \\
\hline Morenguinho & 99.4 & 97.7 & 100 & 98.2 & 97.9 & 98.9 & 97.4 & 100 \\
\hline Parque Mooca & 90.5 & 79.1 & 100 & 100 & 56.7 & 75.5 & 100 & 100 \\
\hline Sapateiro & 100 & 100 & 98.6 & 97.4 & 100 & 100 & 96.8 & 98.3 \\
\hline Saracura & 100 & 100 & 99.2 & 99.2 & 100 & 100 & 98.9 & 98.3 \\
\hline Tiburrinho & 100 & 100 & 98.3 & 98.1 & 100 & 100 & 97.1 & 94.8 \\
\hline Uberaba & 93.5 & 100 & 96.5 & 100 & 99.1 & 88.1 & 100 & 98.5 \\
\hline Verde I & 99.0 & 100 & 98.6 & 98.4 & 100 & 97.2 & 95.5 & 95.8 \\
\hline Verde II & 97.9 & 98.3 & 99.0 & 99.7 & 87.9 & 96.6 & 99.4 & 92.1 \\
\hline Dreno Brooklin & 100 & 92.4 & 96.5 & 96.8 & 99.2 & 100 & 99.5 & 99.0 \\
\hline Pacaembú & 97.7 & 100 & 99.6 & 97.9 & 100 & 98.5 & 98.1 & 99.6 \\
\hline Traição & 93.0 & 99.0 & 98.9 & 90.5 & 96.1 & 71.8 & 96.6 & 99.6 \\
\hline $\begin{array}{l}\text { Vinte e três de } \\
\text { maio }\end{array}$ & 98.5 & 90.2 & 96.1 & 88.2 & 64.9 & 92.4 & 93.5 & 97.9 \\
\hline
\end{tabular}


Table 2. Tree cover, lawn, light exposed land, dark exposed land, shade and dark roof percentages of the watersheds from Ikonos (2002) and Quickbird (2009) satellite images (São Paulo, SP, 2013).

\begin{tabular}{|c|c|c|c|c|c|c|c|c|c|c|c|c|}
\hline \multirow[t]{2}{*}{ Watersheds } & \multicolumn{2}{|c|}{$\begin{array}{c}\text { Tree cover } \\
(\%)\end{array}$} & \multicolumn{2}{|c|}{$\begin{array}{c}\text { Lawn } \\
(\%)\end{array}$} & \multicolumn{2}{|c|}{$\begin{array}{c}\text { Light } \\
\text { exposed } \\
\text { land }(\%)\end{array}$} & \multicolumn{2}{|c|}{$\begin{array}{c}\text { Dark } \\
\text { exposed } \\
\text { land }(\%)\end{array}$} & \multicolumn{2}{|c|}{$\begin{array}{c}\text { Shade } \\
(\%)\end{array}$} & \multicolumn{2}{|c|}{$\begin{array}{c}\text { Dark roof } \\
(\%)\end{array}$} \\
\hline & 2002 & 2009 & 2002 & 2009 & 2002 & 2009 & 2002 & 2009 & 2002 & 2009 & 2002 & 2009 \\
\hline Aclima & .4 & 15.4 & 2.3 & 1.6 & 3.6 & 0.0 & 4.4 & 0.0 & . & 14.1 & 12.5 & 15.9 \\
\hline Anhangabaú & 10.0 & 10.3 & 3.6 & 1.4 & 3.4 & 0.5 & 9.4 & 2.4 & 25.2 & 27.7 & 5.1 & 10.6 \\
\hline Belini & 23.7 & 30.8 & 6.4 & 1.7 & 5.9 & 15.1 & 6.9 & 0.0 & 4.3 & 7.3 & 25.6 & 12.7 \\
\hline Branca & 12.4 & 17.8 & 4.7 & 6.7 & 4.8 & 3.5 & 13.3 & 12.4 & 7.8 & 10.9 & 13.1 & 10.6 \\
\hline Cassandoca & 7.3 & 8.1 & 0.9 & 1.0 & 1.0 & 0.3 & 0.3 & 0.6 & 16.9 & 8.6 & 25.5 & 28.9 \\
\hline Corujas & 15.0 & 22.6 & 7.1 & 3.7 & 6.3 & 0.0 & 7.4 & 0.0 & 10.5 & 13.2 & 8.1 & 18.4 \\
\hline Curtume & 7.6 & 9.3 & 8.1 & 4.2 & 1.9 & 0.0 & 3.0 & 7.1 & 8.4 & 6.5 & 19.7 & 22.1 \\
\hline Luz & 6.3 & 6.4 & 1.3 & 1.1 & 3.4 & 0.8 & 1.8 & 6.7 & 13.6 & 29.8 & 3.5 & 14.6 \\
\hline Fortunatc & 12.3 & 21.7 & 10.6 & 3.1 & 1.6 & 3.5 & 6.0 & 0.0 & 8.0 & 4.6 & 16.8 & 23.3 \\
\hline Glicério & 6.3 & 4.8 & 1.7 & 6.2 & 1.6 & 5.6 & 16.3 & 0.0 & 11.2 & 25.3 & 12.8 & 24.5 \\
\hline Iguatemi & 18.7 & 21.9 & 4.7 & 1.1 & 6.8 & 0.0 & 5.2 & 0.0 & 16.1 & 37.2 & 15.9 & 9.1 \\
\hline Morenguinho & 18.6 & 13.1 & 3.6 & 3.9 & 2.8 & 14.7 & 0.0 & 0.0 & 13.1 & 23.8 & 8.9 & 27.3 \\
\hline Parque Móoca & 10.7 & 6.6 & 3.2 & 0.5 & 9.9 & 0.0 & 6.8 & 0.0 & 8.9 & 15.8 & 4.7 & 13.2 \\
\hline Sapateiro & 22.7 & 24.0 & 2.1 & 3.5 & 0.9 & 1.4 & 4.1 & 0.7 & 6.4 & 15.6 & 11.9 & 18.9 \\
\hline Saracura & 7.9 & 12.3 & 0.1 & 0.7 & 0.0 & 0.0 & 0.0 & 0.0 & 15.7 & 29.8 & 30.1 & 24.2 \\
\hline Tiburrinho & 17.0 & 15.0 & 0.3 & 1.9 & 1.6 & 0.0 & 0.0 & 0.0 & 12.8 & 5.8 & 14.3 & 8.2 \\
\hline Uberaba & 17.1 & 9.1 & 0.2 & 3.7 & 2.6 & 1.5 & 0.0 & 3.7 & 10.5 & 26.3 & 24.7 & 11.7 \\
\hline Verde I & 14.9 & 12.8 & 0.3 & 3.5 & 2.1 & 6.7 & 0.0 & 0.0 & 6.6 & 19.5 & 18.1 & 15.5 \\
\hline Verde II & 21.8 & 26.8 & 0.6 & 1.3 & 2.7 & 0.3 & 0.0 & 1.3 & 7.1 & 18.2 & 23.4 & 19.3 \\
\hline Dreno do Brooklin & 3.7 & 18.7 & 8.7 & 3.8 & 2.0 & 0.0 & 37.8 & 0.0 & 6.5 & 12.4 & 6.0 & 14.6 \\
\hline Pacaembú & 12.7 & 22.0 & 17.2 & 1.8 & 0.0 & 2.1 & 9.7 & 15.3 & 10.5 & 17.5 & 6.2 & 10.9 \\
\hline Traição & 11.9 & 11.8 & 0.3 & 8.4 & 4.2 & 1.9 & 36.6 & 4.6 & 4.7 & 11.0 & 4.2 & 21.0 \\
\hline Vinte e três de maio & 13.3 & 9.4 & 4.1 & 5.1 & 0.0 & 0.0 & 0.0 & 0.0 & 12.7 & 24.0 & 15.8 & 32.6 \\
\hline
\end{tabular}


With these analyses, it was possible to do scatter plots (Figure 1 and 2). Figure 1 shows a determination coefficient of 0.43 , which means there are $43 \%$ correlation between the variables, considered low, and indicates a change in tree cover between 2002 and 2009 in São Paulo city despite showing a tendency to positive correlation.

\section{Tree cover $(\%)$}

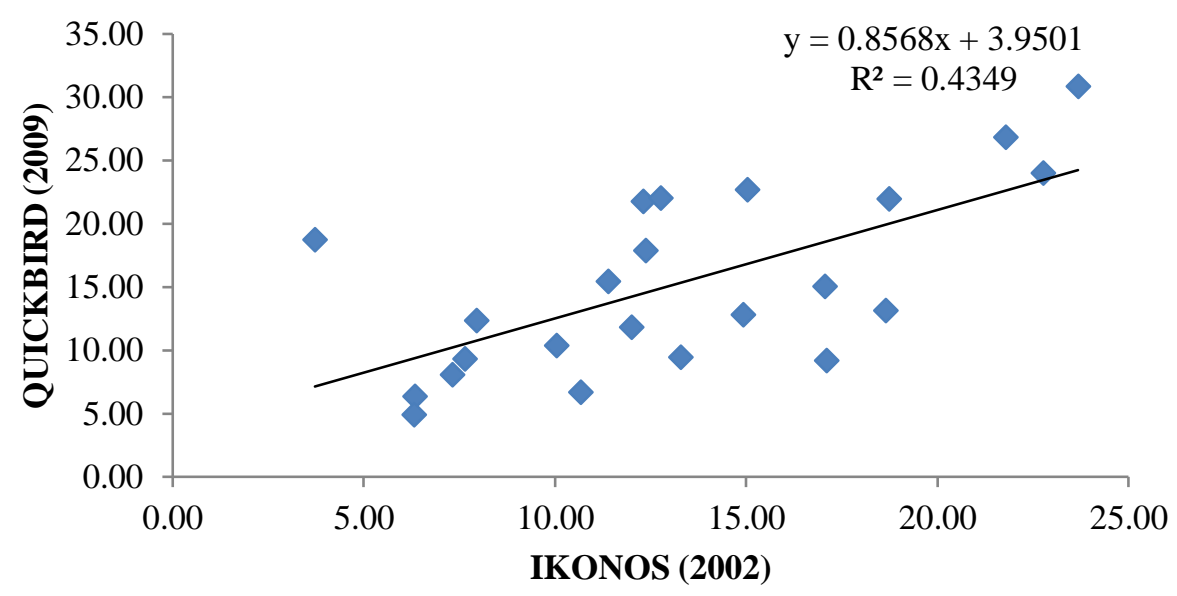

Figure 1. Tree cover percent scatter plots in 2009 and 2002 (São Paulo, SP, 2013).

Analyzing the lawn percentage correlations between 2009 and 2002, the $\mathrm{R}^{2}$ value of 0.0003 (Figure 2) reveals a low value association, demonstrating an even greater change in lawn areas after seven years, without tendency to correlation values. Comparing it to the tree cover $\mathrm{R}^{2}$ value, it is possible to affirm that lawn areas are easier to be occupied and modified than areas with trees, which have their management protected by law. 


\section{Lawn (\%)}

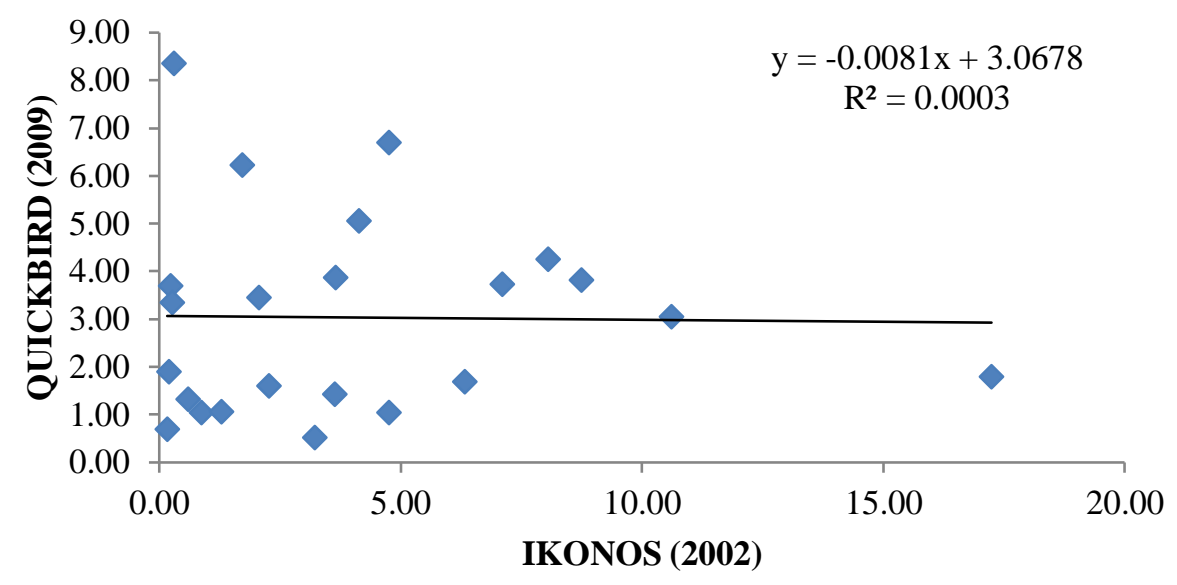

Figure 2. Lawn percent scatter plots in 2009 and 2002 (São Paulo, SP, 2013).

The watersheds description, classes percentage changes from 2002 to 2009 and its possible causes are shown below:

- Aclimação

Tree cover increased 4\%, the lawn area reduced $0.7 \%$ and exposed soil was totally reduced in 2009 (Table 2). It is suggested that exposed soil area gave way to the trees.

- Belini

An increase of $7.1 \%$ in tree cover and $4.6 \%$ lawn reduction (Table 2) suggests tree occupation in lawn areas.

- Branca

An upgrade of $5.4 \%$ in tree cover (Table 2) can be explained by trees growth after seven years and the presence of clouds blocking part of the image of Ikonos satellite (2002) that are absent in Quickbird satellite images (2009).

- Corujas

Tree cover increased $7.6 \%$ while lawn reduced $3.37 \%$ (Table 2), the hypothesis are that trees have grown on law areas and the clouds presence in Ikonos satellite image (2002).

- Fortunato Ferraz

There was an increase of $9.4 \%$ in tree cover, a decrease of $7.5 \%$ of lawn and $6 \%$ in dark exposed land (Table 2), probably due to trees extent on these areas. 
- Morenguinho

It was observed a decrease of $5.5 \%$ in tree cover that is probably related to the increase of $18.4 \%$ of dark roof and $10.6 \%$ of shade (Table 2) that occupied green areas. In cities vertical occupation it is normal that shadows increase, together with roofs due to the large buildings structures (SOUZA, 1994).

- Saracura

It was observed an increase of $4.4 \%$ in tree cover and $0.5 \%$ in lawn area in contrast to the decrease of all others classes (Table 2).

- Córrego Uberaba

A decrease of $7.9 \%$ in tree cover and $1.2 \%$ in light exposed soil in combination to an increase of $3.4 \%$ in lawn area and $16.1 \%$ in shade (Table 2) suggests an intensive land use change in this area.

- Córrego Verde II

Tree cover and lawn had a growth of $5.0 \%$ and $0.7 \%$, respectively, which may be related to a $2.4 \%$ light exposed soil decrease (Table 2).

- Dreno do Brooklin

There was an increase of $15 \%$ in tree cover and a reduction of $4.9 \%$ in lawn area (Table 2) probably because of tree growth, pruning, planting seedlings and others. It is necessary to consider that occurred a slight confusion between these classes due to Ikonos satellite image resolution.

- Pacaembú

Tree cover increased $9.2 \%$ while lawn area had a reduction of $15.4 \%$, which may have been occupied by dark exposed soil, which increased 5.6\% (Table 2). There was also a confusion between tree cover and lawn classes in the Ikonos satellite image.

- Traição

Dark exposed soil had an intense reduction of $31.9 \%$, because it has probably taken by lawn areas that grew $8 \%$ (Table 2).

Analyzing the total area of São Paulo city, while 125\% of exposed soil decreased from 2002 to 2009, roofs and shadows show a growth of $122.4 \%$ and $157.7 \%$ (Table 2), respectively, which means that exposed soil of 2002 may have been occupied by buildings in 2009, which we can see in Figures 3 , 4 and 5. 


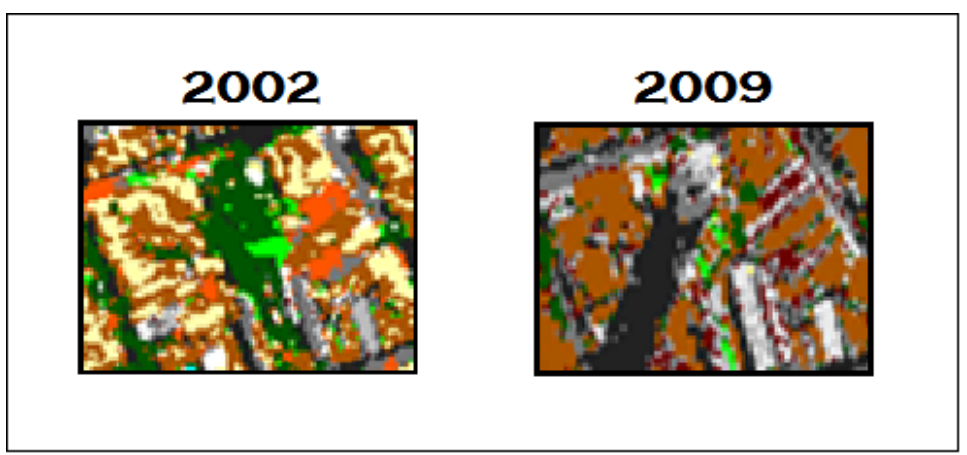

Figure 3. Exposed soil area in 2002 occupied by roofs and a building in 2009 in the Branca watershed (São Paulo, SP, 2013).

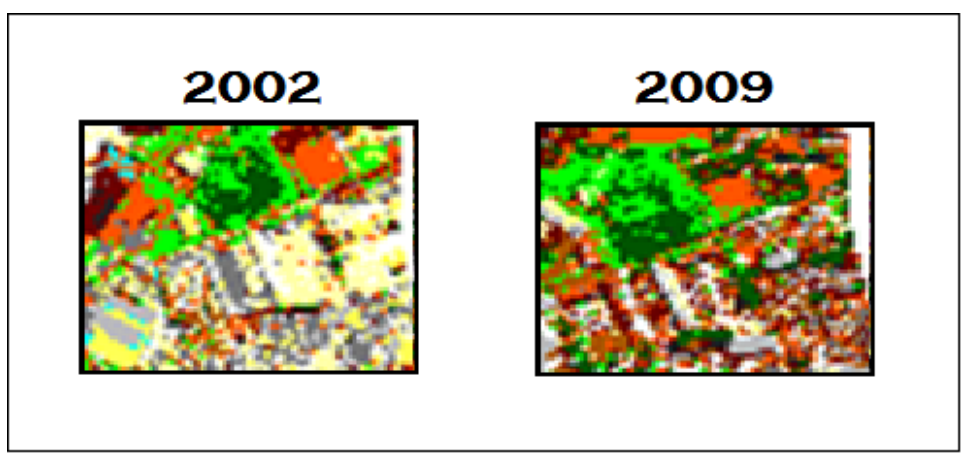

Figure 4. Exposed soil area in 2002 occupied by ceramic and metallic roofs in 2009 in the Tiburrinho watershed (São Paulo, SP, 2013).

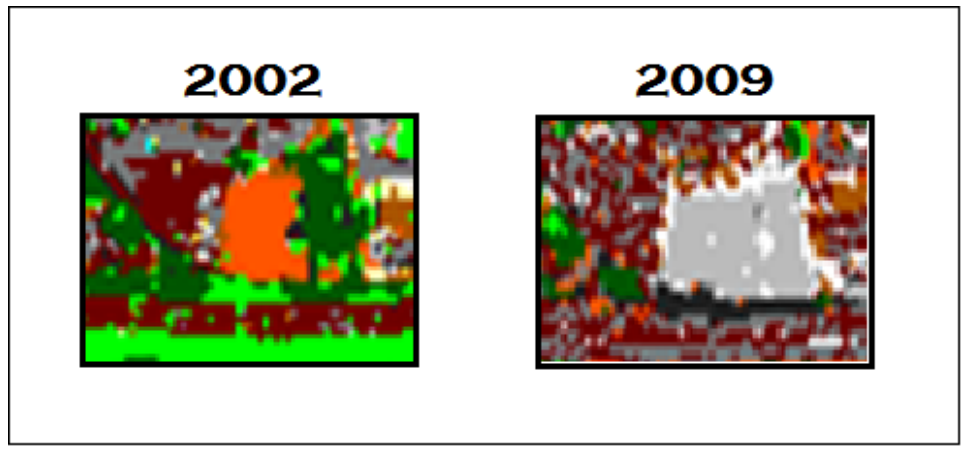

Figure 5. Exposed soil, trees and lawn areas in 2002 occupied by constructions in 2009 in the Parque da Mooca watershed (São Paulo, SP, 2013).

The watershed with a higher tree cover is Belini, both in 2002 and in 2009, followed by Sapateiro and Verde II in 2002 and by Verde II and Sapateiro in 2009 (Table 3). On the other hand, those with lower tree cover were Dreno do Brooklin (2002) and Glicério (2009), according to Table 3. 
Table 3. Watersheds ranking according to tree cover percentage in the Ikonos (2002) and Quickbird (2009) satellite images (São Paulo, SP, 2013).

\begin{tabular}{|c|c|c|c|c|c|}
\hline \multicolumn{3}{|c|}{ Ikonos satellite (2002) } & \multicolumn{3}{|c|}{ Quickbird satellite (2009) } \\
\hline Ranking & Watersheds & $\begin{array}{c}\text { Tree } \\
\text { cover } \\
(\%)\end{array}$ & Ranking & Watersheds & $\begin{array}{c}\text { Tree } \\
\text { cover } \\
(\%)\end{array}$ \\
\hline $1^{\circ}$ & Belini & 23.68 & $1^{\circ}$ & Belini & 30.85 \\
\hline $2^{o}$ & Sapateiro & 22.77 & $2^{o}$ & Verde II & 26.83 \\
\hline $3^{\circ}$ & Verde II & 21.79 & $3^{\circ}$ & Sapateiro & 23.98 \\
\hline $4^{\mathrm{o}}$ & Iguatemi & 18.73 & $4^{\circ}$ & Corujas & 22.64 \\
\hline $5^{\circ}$ & Morenguinho & 18.65 & $5^{\circ}$ & Pacaembú & 22.03 \\
\hline $6^{\circ}$ & Uberaba & 17.10 & $6^{\circ}$ & Iguatemi & 21.95 \\
\hline $7^{\circ}$ & Tiburrinho & 17.05 & $7^{\circ}$ & Fort Ferraz & 21.75 \\
\hline $8^{\circ}$ & Corujas & 15.02 & $8^{\circ}$ & Dreno do Brooklin & 18.73 \\
\hline $9^{\circ}$ & Verde I & 14.92 & $9^{\circ}$ & Branca & 17.84 \\
\hline $10^{\circ}$ & Vinte e três de maio & 13.28 & $10^{\circ}$ & Aclimação & 15.44 \\
\hline $11^{\circ}$ & Pacaembú & 12.76 & $11^{\circ}$ & Tiburrinho & 14.99 \\
\hline $12^{\circ}$ & Branca & 12.37 & $12^{\circ}$ & Morenguinho & 13.10 \\
\hline $13^{\circ}$ & Fort Ferraz & 12.30 & $13^{\circ}$ & Verde I & 12.76 \\
\hline $14^{\circ}$ & Traição & 11.99 & $14^{\circ}$ & Saracura & 12.34 \\
\hline $15^{\circ}$ & Aclimação & 11.39 & $15^{\circ}$ & Traição & 11.78 \\
\hline $16^{\circ}$ & Parque da Móoca & 10.68 & $16^{\circ}$ & Anhangabaú & 10.31 \\
\hline $17^{\circ}$ & Anhangabaú & 10.05 & $17^{\circ}$ & Vinte e três de maio & 9.42 \\
\hline $18^{\circ}$ & Saracura & 7.94 & $18^{\circ}$ & Curtume & 9.31 \\
\hline $19^{\circ}$ & Curtume & 7.64 & $19^{\circ}$ & Uberaba & 9.14 \\
\hline $20^{\circ}$ & Cassandoca & 7.31 & $20^{\circ}$ & Cassandoca & 8.06 \\
\hline $21^{\circ}$ & da Luz & 6.33 & $21^{\circ}$ & Parque da Móoca & 6.62 \\
\hline $22^{\circ}$ & Glicério & 6.30 & $22^{\circ}$ & da Luz & 6.36 \\
\hline $23^{\circ}$ & Dreno do Brooklin & 3.72 & $23^{\circ}$ & Glicério & 4.88 \\
\hline
\end{tabular}


The Dreno do Brooklinwatershed, in seven years, presented a growth of $15.01 \%$ in tree cover, which is very expressive compared to other areas (Table 3). The tree cover percentages revealed a variation between $3.72 \%$ and $23.68 \%$ in 2002, and variation between $4.88 \%$ and $30.85 \%$ in 2009 (Table 3).

São Paulo urbanization has intensely increased during that period andmost areas were occupied by asphalt, which entails significant microclimate change. Urban forest has increased in several regions but it is still far from representing a minimal ideal index. It is necessary that the management sector responsible to these watersheds rethink their administrative actions and how they focus on protecting and increasing their green areas over the years.

\section{ACKNOWLEDGEMENTS}

To all who participated and assisted in obtaining the materials for study, to the Urban Forestry Laboratory from Forest Science Department of ESALQ/USP, for the support and resources made available to the research full execution

\section{REFERENCES}

BAESSO, R. S.; SOUZA, A. A. 2010. O coeficiente de determinação é uma medida confiável do poder explicativo de modelos de estimação do valor intrínseco das ações negociadas na Bovespa? In: CONGRESSO USP CONTROLADORIA E CONTABILIDADE, 10., Belo Horizonte. Anais. Belo Horizonte: UFMG. p. 1-17.

BONAMETTI, J. H. 2003. Arborização urbana. Revista Terra e Cultura, Londrina, year XIX, n. 36, p. 51-55.

CENTRO DE PESQUISAS METEOROLOGICAS E CLIMÁTICAS APLICADAS A AGRICULTURA, CEPAGRI. 2013. Available in: <http://www.cpa.unicamp.br/outrasinformacoes/clima_muni_565.html>. Access May 2013.

CONGALTON, R. G. 2001. Accuracy assessment and validation of remotely sensed and other spatial information. International Journal of Wildland Fire, Clayton South, v. 10, p. 321-328.

CONTI, F. 2009. Biometria, Regressão e Correlação. Universidade Federal do Pará. Available in: <http://www.ufpa.br/dicas/biome/biopdf/bioreg.pdf>. Access June 2013.

FERREIRA, E.; DANTAS, A. A. A.; MORAIS, A. R. 2007. Exatidão na classificação de fragmentos de matas em imagem do satélite Cbers-CCD, no município de Lavras, MG. In: SIMPÓSIO BRASILEIRO DE SENSORIAMENTO REMOTO, 8., Florianópolis. Anais. Florianópolis: INPE. p. 887-894.

INSTITUTO BRASILEIRO DE GEOGRAFIA E ESTATÍSTICA, IBGE. 2013. Available in: <http://www.ibge.gov.br/home/default.php>. Access May 2013.

KOTTEK, M.; GRIESER, J.; BECK, C.; RUDOLF, B.; RUBEL, F. 2006. World Map of the KöppenGeiger climate classification updated. Meteorol. Z., Stuttgart, v. 15, p. 259-263. 
LANDIS, J. R.; KOCH, G. G. 1977. The measurement of observer agreement for categorical data. Biometrics, Washington, v. 33, n. 1, p. 159-174.

LOMBARDO, M. A. 1990. Vegetação e clima. In: ENCONTRO NACIONAL SOBRE ARBORIZAÇÃO URBANA, 3., Curitiba. Anais. Curitiba: Impresso na Fundação de Pesquisas Florestais do Paraná. p. 1-13.

MOREIRA, T. C. L.; SILVA FILHO, D. F.; POLIZEL, J. L. 2007. Extração de cobertura arbórea intraurbana de imagens de alta resolução. In: SIMPÓSIO BRASILEIRO DE SENSORIAMENTO REMOTO, 13., Florianópolis. Anais. Curitiba: INPE, p. 5403-5409.

NOWAK, D. J.; ROWNTREE, R. A.; MCPHERSON, E. G.; SISINNI, S. M.; KERKMANN, E. R.; STEVENS, J. C. 1996. Measuring and analyzing urban tree cover. Landscape and Urban Planning, Amsterdam, v. 36, p. 49-57.

SILVA FILHO, D. F. 2006. Videografia aérea multiespectral em silvicultura urbana. Ambiência, Guarapuava, v. 2, p. 55-68.

SOUZA, M. A. A. 1994. A identidade da metrópole: a verticalização em São Paulo. Coleção Estudos urbanos. Editora Hucitec, v. 8, 257 p.

XIAO, Q.; USTIN, S.; MCPHERSON, E. G.; PEPER, P. 1999. Characterization of the structure and species composition of urban trees using high resolution AVIRIS data. In: SUMMARIES OF THE EIGHT JPL AIRBORNE EARTH SCIENCE WORKSHOP, 8., Pasadena. Proceedings... Pasadena: California Institute of Technology, Jet Propulsion Laboratory, p. 451-460. 